\title{
EFFECTS OF CADMIUM - SALT INTERACTIONS ON GROWTH AND SOME GENES IN WHEAT
}

\author{
DOĞRU, H. - ERGÜN, N.* \\ Mustafa Kemal University, Science and Art Faculty, Biology Department, Antakya, Hatay, \\ Turkey \\ ${ }^{*}$ Corresponding author \\ e-mail: ergun.nuray@gmail.com \\ (Received $11^{\text {th }}$ Jul 2020; accepted $19^{\text {th }}$ Jan 2021)
}

\begin{abstract}
Due to the increase in human population and anthropogenic factors, agricultural lands have been affected by salinization and heavy metal pollution has increased. In this study, the effects of cadmium and salt interactions on Konya - 2002 and Dağdaş - 94 varieties of Triticum aestivum L. seedlings were investigated. Catalase and glutathione reductase activities were determined as well as proline content and expression of TaMYB73, TaSRG and TaERF1 genes. Cd and salt applications caused an increase in catalase, glutathione reductase activities and free proline content in both cultivars. With $\mathrm{Cd}$ and salt applications, Dağdaş - 94 variety was more resistant than Konya - 2002. TaMYB73 expression did not increase under either treatment. Dağdaş exhibited the highest increase in gene expression. High $\mathrm{NaCl}$ and $\mathrm{Cd}$ concentrations caused an increase in ERF1 expression in Dağdaş variety. Increased TaSRG expression in Dağdaş under low $\mathrm{NaCl}$ concentrations has probably been associated with salt tolerance. Increased TaSRG expression with $\mathrm{Cd}$ administration in Konya probably corresponded to genes related to Cd resistance.
\end{abstract}

Keywords: catalase, glutathione reductase, TaMYB73, TaSRG, TaERF1

\section{Introduction}

Cereals meet half of the protein and carbohydrate requirements of humans. Therefore, they rank first among the cereals cultivated (Durán et al., 2007).

Currently, abiotic stress (including temperature, water, light, $\mathrm{NaCl}$ and $\mathrm{pH}$ ) leads to the loss of more than half of the product. Salinity affects the yield of soils used to cultivate wheat (Triticum aestivum L.), leading to the inefficiency of 10 million hectares of land annually. Salt stress is mainly caused by evaporation and lack of rainfall (Doğan and Çarpic1, 2015).

Salt stress reduces the growth and yield of plants, especially in climatic zones with low rainfall. Salinity is a major threat to modern agriculture, hindering crop growth and development (Isayenkov and Maathius, 2019). Salts in the soil dissolve with irrigation and rainfall; leaking to lower soil layers; and may even reach the sea, which can mix with groundwater. In arid regions, salt washing and evaporation lead to the accumulation of salt on the soil surface referred to as salt stress.

High concentrations of salt ions in salty soils lead to reduced water absorption in plants, rendering toxic effects and enzymatic activity changes. The deterioration in the ion balance and lack of water reduces the nutrient transport and membrane permeability of plants. Vital functions in plants such as photosynthesis and respiration are inhibited; the growth of roots and aboveground parts is retarded; and the number of buds decreases.

According to Doğan and Çarpıcı (2015), salty lands were reportedly improved by the elimination of infertile effects of saline soils; however, the methods for this 
improvement are time - consuming and exhausting. Therefore, the selection of saltresistant species and varieties in saline soils is very important. Species grown in suitable environments will increase the yield, and hence wheat production.

Currently, heavy metal pollution is gradually increasing worldwide due to industrialization and human activities. Cadmium $(\mathrm{Cd}$, the atomic number of 48$)$ is a heavy metal that exerts a serious threat to human health; it is one of the most dangerous heavy metal pollutants in the ecosystem, and it is toxic to living organisms. Due to the long - term use of phosphorous manure and sewage sludge, low or moderate concentrations of cadmium are observed in agricultural soils in several parts of the world (Tirry et al., 2018). Meanwhile, proline is a key osmoregulatory amino acid that ensures the integrity of proteins as well as activates enzymes in plants under salt $(\mathrm{NaCl})$ stress. Proline content increases when plants are exposed to stress conditions (Öncel et al., 2000).

Heavy - metal contamination in plants causes genotoxic effects; thus, mutation - like changes are observed in the DNA structure. Batır (2014) has examined the effect of lead $(\mathrm{Pb})$ and copper $(\mathrm{Cu})$ on artichoke (Cynara scolymus L.) seedlings by physiological, biochemical and molecular methods. Different concentrations of heavy metals lead to a decrease in the root length and ratio of the total soluble protein in seedlings. The randomly amplified polymorphic DNA - polymerase chain reaction Randomly Amplified Polymorphic DNA - Polymerase Chain Reaction (RAPD - PCR) screening method was employed to determine the genotoxic effects of heavy metal stress on seedlings. Compared to control group seedlings, those exposed to heavy metal stress exhibit different changes such as new bands and/or loss of bands in their RAPD profiles. As a result, the genomic template stability of artichoke seedlings exposed to $\mathrm{Pb}$ and $\mathrm{Cu}$ stress changes according to their RAPD profiles.

He et al. (2012) have reported that the TaMYB73 (myeloblastosis oncogene) gene stimulates $\mathrm{NaCl}$ dehydration and several phytohormones under $\mathrm{NaCl}$ stress conditions and that the overexpression of the relevant gene increases the tolerance to salt stress by playing a role in the ionic stress response in Arabidopsis. MYB is a transcription factor. Previously, the MYB transcription factor has been reported to play a role in plant responses to biotic and abiotic stresses, cell development and signal transfer (Wang et al., 2016).

He et al. (2011) have reported that the wheat TaSRG gene serves as a transcription agent in plant varieties and increases tolerance. Also, in their study, the TaSRG gene function is related to salt tolerance. Ethylene - responsive factor (ERF) transcription factors constitute a family including 147 members according to plant species. The ERF gene expression is crucial for adaptation to several biotic and abiotic stresses (Cheng et al., 2013).

Wheat plays an important role in the nutrition of the population in the world and Turkey. Abiotic factors such as salt and heavy metal pollution are known to decrease wheat yield. Therefore, the selection of both stress-resistant wheat varieties is a decisive factor for agricultural production. It is known that plants develop tolerance to stress factors. It is important to determine the biochemical, physiological and molecular mechanisms that ensure the tolerance of wheat to salt and heavy metal stress.

Owing to the limited number of studies on the salt application in wheat seedlings exposed to heavy metal stress, in this study, effects of the applications of salt $(100 \mathrm{mM}$, $200 \mathrm{mM})$, cadmium $(10 \mathrm{mM})$ and salt-cadmium $(100 \mathrm{mM} \mathrm{NaCl}+10 \mathrm{mM} \mathrm{Cd}, 200 \mathrm{mM}$ $\mathrm{NaCl}+10 \mathrm{mM} \mathrm{Cd}$ ) on the free proline content, as well as CAT and GR activities, on 
wheat (T. aestivum L. cv. Konya - 2002, Dağdaş - 94) seedlings were investigated, and biochemical parameters, as well as TaMYB73, TaSRG, TaERF transcription factors, were examined by molecular biological methods. Also, the Konya - 2002 and Dağdaş - 94 wheat varieties were compared in terms of the specified parameters, and whether these varieties exhibit tolerance to different salt concentrations and Cd stress was investigated. Biochemical studies were spectrophotometrically conducted for CAT and GR activities and free proline content, and real-time PCR (RT - PCR) was employed for TaMYB73, TaSRG and TaERF.

\section{Materials and Methods}

\section{Materials}

Wheat is one of the most important cereal in Turkey. Therefore, our study common varieties of wheat produced in Turkey (T. aestivum L. cv. Konya - 2002 and T. aestivum L. cv Dağdaş -94) were used. Wheat seeds were obtained from the Directorate of Bahri Dağdaş International Agricultural Research Institute (Konya, Turkey). The Konya - 2002 wheat variety is known to be sensitive to drought but exhibits good resistance to incubation, winter and cold (Anonym, 2020). The Dağdaş - 94 wheat variety is known to be resistant to drought, incubation and cold (Öztürk and Aydin, 2017).

\section{Methods}

\section{Plant Growth Conditions}

Seeds were sterilized by 20 - min incubation in a $2 \%$ sodium hypochlorite solution, washed with pure water, and incubated in pure water for $1 \mathrm{~h}$ to swell. Then, the seeds were placed in perlite - containing pots and incubated at $24 \pm 2{ }^{\circ} \mathrm{C}$ for germination. The seeds were watered with $200 \mathrm{~mL}$ of pure water on average for 7 days and transferred to 1 - L plastic pots containing the Arnon-Hoagland nutrient solution after germination. Seedlings in the plastic pots were grown at $24 / 16^{\circ} \mathrm{C}$ day/night conditions for 5 days. At the end of the fifth day, the pots were divided into 12 groups (Öncel et al., 2000; Ergün and Öncel, 2012).

Group 1 (Konya control): The growth conditions $\left(24 / 16{ }^{\circ} \mathrm{C}\right.$ day/night) were maintained constant since the day the seedlings were taken into the water culture on the $10^{\text {th }}$ day.

Group 2 (Konya $\mathrm{NaCl} 100 \mathrm{mM}$ ): The seedlings were treated with $100 \mathrm{mM} \mathrm{NaCl}$ on the $6^{\text {th }}$ day.

Group 3 (Konya cadmium group): The seedlings were treated with $10 \mathrm{mM} \mathrm{Cd}$ at the beginning of the $6^{\text {th }}$ day.

Group 4 (Konya $\mathrm{NaCl} 100 \mathrm{mM}+$ cadmium): The seedlings were treated with 100 $\mathrm{mM} \mathrm{NaCl}$ and $10 \mathrm{mM} \mathrm{Cd}$ at the beginning of the $6^{\text {th }}$ day.

Group 5 (Konya $\mathrm{NaCl} 200 \mathrm{mM}$ ): The seedlings were treated with $200 \mathrm{mM} \mathrm{NaCl}$ on the $6^{\text {th }}$ day.

Group 6 (Konya $\mathrm{NaCl} 200 \mathrm{mM}+$ cadmium): The seedlings were treated with 200 $\mathrm{mM} \mathrm{NaCl}$ and $10 \mathrm{mM} \mathrm{Cd}$ at the beginning of the $6^{\text {th }}$ day.

Group 7 (Dağdaş control): The growth conditions $\left(24 / 16{ }^{\circ} \mathrm{C}\right.$ day/night) were maintained constant since the day the seedlings were taken into the water culture on the $10^{\text {th }}$ day. 
Group 8 (Dağdaş $\mathrm{NaCl} 100 \mathrm{mM}$ ): The seedlings were treated with $100 \mathrm{mM} \mathrm{NaCl}$ on the $6^{\text {th }}$ day.

Group 9 (Dağdaş cadmium group): The seedlings were treated with $10 \mathrm{mM} \mathrm{Cd}$ at the beginning of the $6^{\text {th }}$ day.

Group 10 (Dağdaş $\mathrm{NaCl} 100 \mathrm{mM}+$ cadmium): The seedlings were treated with $100 \mathrm{mM} \mathrm{NaCl}$ and $10 \mathrm{mM} \mathrm{Cd}$ at the beginning of the $6^{\text {th }}$ day.

Group 11 (Dağdaş $\mathrm{NaCl} 200 \mathrm{mM}$ ): The seedlings were treated with $200 \mathrm{mM} \mathrm{NaCl}$ on the $6^{\text {th }}$ day.

Group 12 (Dağdaş $\mathrm{NaCl} 200 \mathrm{mM}+$ cadmium): The seedlings were treated with $200 \mathrm{mM} \mathrm{NaCl}$ and $10 \mathrm{mM} \mathrm{Cd}$ at the beginning of the $6^{\text {th }}$ day.

In our study, each experiment was conducted in triplicate. During the experiment, the location of the containers was randomly changed in a clockwise direction. The wheat seedlings were harvested on the $10^{\text {th }}$ day. After harvesting, the shoot parts of the seedlings were cut into small pieces for some analyses (i.e. CAT, GR and free proline), labelled according to the group number of the seedlings and stored at $-80{ }^{\circ} \mathrm{C}$ in a deep freezer. Samples were repeatedly prepared three times. The SPSS program was used for statistical analysis. Arithmetic means standard deviations and standard errors of the experimental results were calculated. Duncan's multiple range test was employed to determine the significant differences between means.

Glutathione reductase (GR) activity was measured according to Cakmak and Marschner (1992) and Çakmak (1994). Catalase enzyme activity (CAT) was measured at $240 \mathrm{~nm}$ in a spectrophotometer due to the fragmentation rate of $\mathrm{H}_{2} \mathrm{O}_{2}$. The reaction mixture consists of $(1 \mathrm{ml}), 50 \mathrm{mM}$ phosphorus buffer $(\mathrm{pH} \mathrm{7.6}), 0.1 \mathrm{mM}$ EDTA, $100 \mathrm{mM} \mathrm{H} \mathrm{H}_{2} \mathrm{O}_{2}$ and enzyme extract (Çakmak and Marschner, 1992). Free proline extraction and determination made according to Bates et al. (1973).

Determination of gene expressions was measured the wheat samples were exposed to cadmium and salt stresses and grown under specific conditions for a certain period. Then, leaf samples were collected after harvest and placed in liquid nitrogen. The samples were stored at $-80{ }^{\circ} \mathrm{C}$ until RNA analyses were performed. For total RNA isolation and reverse transcription about $1 \mathrm{~g}$ of wheat leaves divided into small pieces and taken into $2 \mathrm{ml}$ tube and these analyzes was made considering the work of Ergün et al. (2014).

Quantitative real-time PCR (Q - PCR) Protocol; The Biospeedy ${ }^{\mathrm{TM}}$ Relative Count Kit (Turkey) was used to determine the gene expression level in 12 wheat samples exposed to different stress factors. All genes were studied in 3 replicates and $2^{\wedge}-\Delta \Delta \mathrm{Ct}$ Method (Livak and Schmittgen, 2001) was used for the experiment.

The kit included target genes of the MYB73 gene encoding putative transcription factor, ERF1 gene encoding ethylene-responsive factor 1, and T. aestivum salt response, or TaSRG, gene. Actin was used as the housekeeping gene, which encodes a protein in wheat, to normalize expression levels of target genes. The kit included primers specific to the housekeeping and target genes as well as the enzymes and buffers required for RT - PCR.

The Roche LC 96 (Roche, Switzerland) RT - PCR instrument was employed for all reactions. The reaction contained $1.5 \mathrm{mM} \mathrm{MgCl}_{2}, 0.2 \mathrm{mM} \mathrm{dNTP}$ mix, $1 \mathrm{x}$ reaction buffer, 0.1U Fast Start Taq DNA polymerase, $1 \times$ EvaGreen, $4 \mathrm{ng} / \mu \mathrm{L}$ of template cDNA and $0.5 \mu \mathrm{M}$ of each primer. In the instrument, annealing temperatures specific to the primer pairs (Table 1) and the optimized reaction cycle temperatures were utilized. During qPCR, melt curve analysis was performed only between $65{ }^{\circ} \mathrm{C}$ and $98{ }^{\circ} \mathrm{C}$ to 
ensure that only the desired product was amplified. qPCR data were analysed by Roche Lightcycler 96 Software 1.1.

Table 1. Names, code names, sequences and amplicon lengths of the primers used in the study

\begin{tabular}{|c|c|c|c|}
\hline Primer Name & Sequence $\left(5^{\prime}-3^{\prime}\right)$ & $\begin{array}{c}\text { Annealing } \\
\text { Temperature }^{\circ} \mathrm{C} \\
\end{array}$ & Reference \\
\hline $\begin{array}{c}\text { TaSRG - F }(T \text {. } \\
\text { aestivum salt response } \\
\text { gene) }\end{array}$ & GAAGATGGAGGTCAGGGACA & \multirow[t]{2}{*}{56} & \multirow[t]{2}{*}{$\begin{array}{c}\text { Ergün, Kolukırık, } \\
2014\end{array}$} \\
\hline TaSRG - R & AGCTCTTGCTGAGAGGCTTG & & \\
\hline ActinF & GTCGGTGAAGGGGACTTACA & \multirow{2}{*}{55} & \multirow{2}{*}{$\begin{array}{l}\text { Ergün, Kolukırık, } \\
2014\end{array}$} \\
\hline ActinR & TTCATACAGCAGGCAAGCAC & & \\
\hline $\begin{array}{l}\text { ERF1 - F (Ethylene - } \\
\text { responsive factor1) }\end{array}$ & TCCTGTGATGGGTGATGCTA & \multirow[t]{2}{*}{54} & \multirow{2}{*}{$\begin{array}{c}\text { Ergün, Kolukırık, } \\
2014\end{array}$} \\
\hline ERF1 - R & AGGGCATGTCATCAAAGGTC & & \\
\hline $\begin{array}{c}\text { MYB73 - F } \\
\text { (myeloblastosis } \\
\text { oncogene) }\end{array}$ & GACAGCTTCTGGTCGGAGAC & \multirow[t]{2}{*}{54} & \multirow[t]{2}{*}{$\begin{array}{c}\text { Ergün, Kolukırık, } \\
2014\end{array}$} \\
\hline MYB73 - R & CGACGACGGCGATAAACTAT & & \\
\hline
\end{tabular}

\section{Data Evaluation}

The data of the study group were shown as mean \pm standard error. The data related to the application groups were analyzed with One-Way Anova in SPSS 22.00 program and the differences between the means were compared with Duncan multiple comparison test (SPSS, 2019). For gene analysis; Arc Stat XLISPPLUS version 3.04 (http://www.stat.umn.edu/arc/software.html) software was employed for PCR data, and the MacAnova (http://www.stat.umn.edu/macanova/) program was employed for variance analysis. Fisher's protected least - significant test was employed to compare the mean threshold cycle values $(\mathrm{Ct})(\mathrm{p}<0.05)$.

\section{Results}

The obtained results were examined to determine the differences between the control group wheat seedlings (T. aestivum L. cv. Konya - 2002 and T. aestivum L. cv. Dağdaş - 94) and seedlings exposed to salt and Cd. The CAT and GR activities and proline accumulation in wheat seedlings, as well as RT - PCR analyses of TaMYB73, TaSRG and TaERF1 transcription factors expressed under stress conditions, were investigated.

\section{Effects on Catalase and Glutathione Reductase Activities}

The CAT activity in wheat seedlings of the Dağdaş - 94 variety was greater than that of the Konya - 2002 variety ( $p \leq 0.01)$. Compared to the salt application ( $p \leq 0.05)$, by the Cd application, the CAT activity increase was greater for the wheat seedlings of the Dağdaş - 94 variety (Fig. 1). 


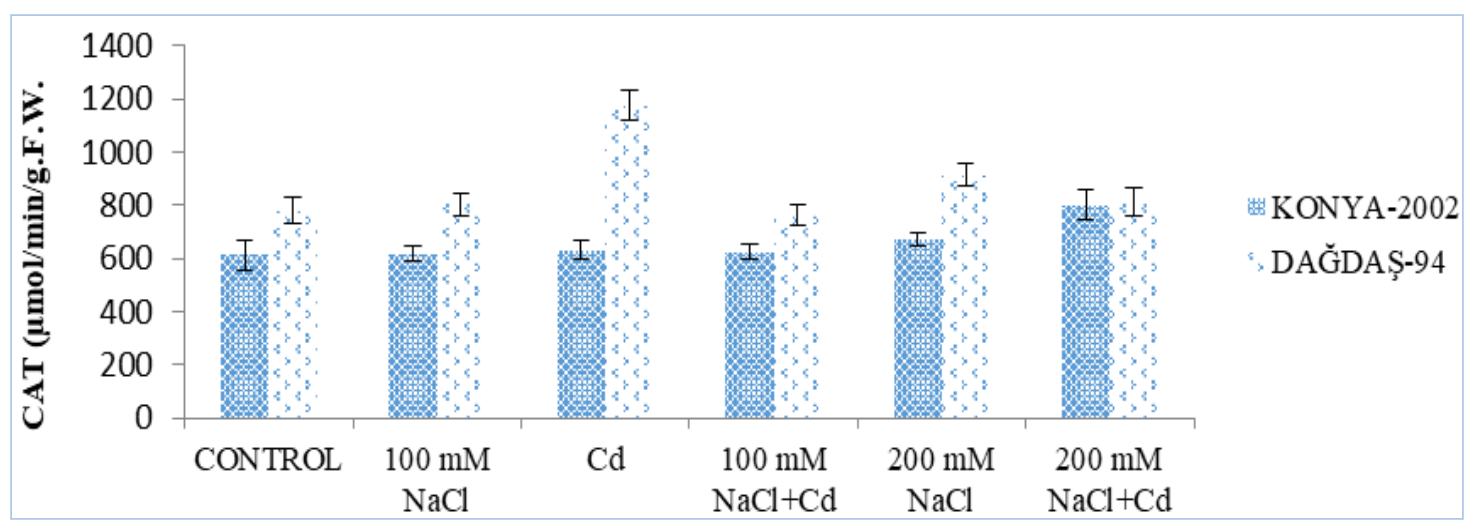

Figure 1. Changes in the catalase activity of wheat (T. aestivum L. cv. Konya - 2002 and T. aestivum L. cv. Dağdaş - 94) samples grown under $100 \mathrm{mM} \mathrm{NaCl}, \mathrm{Cd}, 100 \mathrm{mM} \mathrm{NaCl}+\mathrm{Cd}$, $200 \mathrm{mM} \mathrm{NaCl}$ and $200 \mathrm{mM} \mathrm{NaCl}+\mathrm{Cd}$ conditions $(n=3)$

By applications of $10 \mathrm{mM} \mathrm{Cd}$ and $200 \mathrm{mM} \mathrm{NaCl}+10 \mathrm{mM} \mathrm{Cd}$ compared to the control, the Konya - 2002 seedlings exhibited an $\sim 2$ - fold increase in the GR activity. By applications of $10 \mathrm{mM} \mathrm{Cd}$ and $200 \mathrm{mM} \mathrm{NaCl}+10 \mathrm{mM} \mathrm{Cd}$ compared to the control ( $\mathrm{p} \leq 0.01$ ), the Dağdaş - 94 seedlings exhibited an $\sim 3$ - fold increase in the GR enzyme activity (Fig. 2).

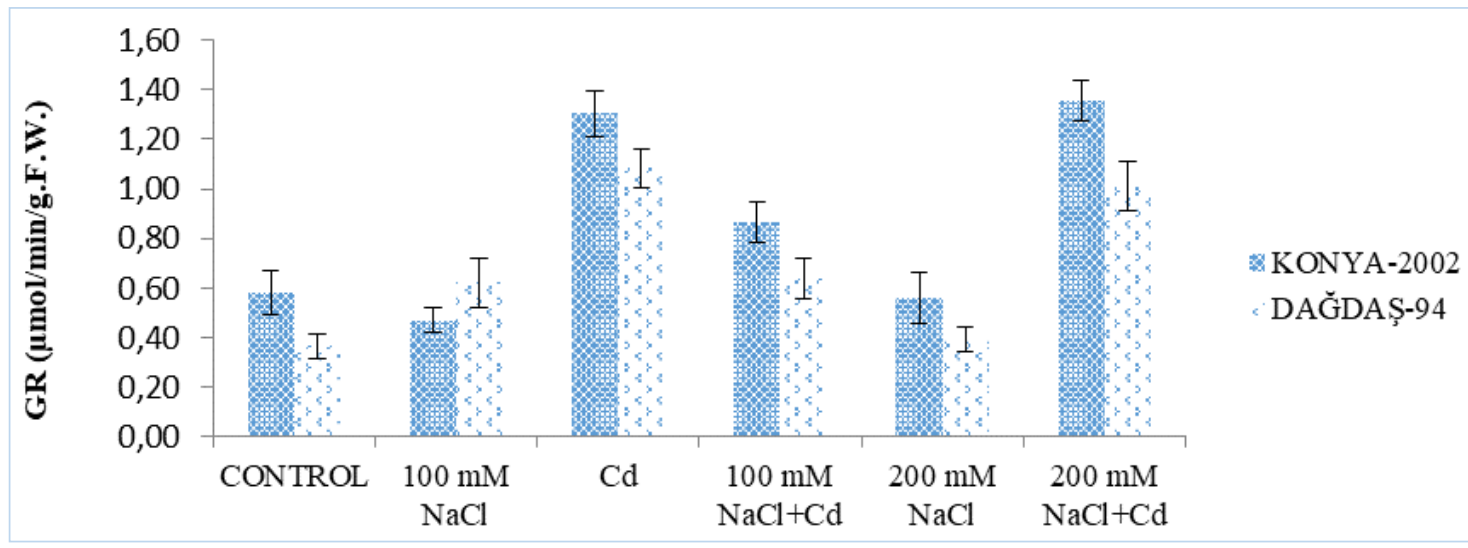

Figure 2. Changes in the glutathione reductase activity of wheat (T. aestivum L. cv. Konya2002 and T. aestivum L. cv. Dağdaş - 94) samples grown under $100 \mathrm{mM} \mathrm{NaCl}, \mathrm{Cd}, 100 \mathrm{mM}$ $\mathrm{NaCl}+\mathrm{Cd}, 200 \mathrm{mM} \mathrm{NaCl}$ and $200 \mathrm{mM} \mathrm{NaCl}+\mathrm{Cd}$ conditions $(n=3)$

\section{Proline Content}

The accumulation of proline increased with stress application in both wheat varieties. The amount of proline in wheat seedlings of Konya - 2002 variety increased by 10 times more than the control samples by the application of $200 \mathrm{mM} \mathrm{NaCl}(\mathrm{p} \leq 0.01)$. By the application of $200 \mathrm{mM} \mathrm{NaCl}+10 \mathrm{mM} \mathrm{Cd}$ compared to the Cd only application, the Konya - 2002 seedlings exhibited an $\sim 11$ - fold increase in the proline accumulation. In Dağdas - 94 seedlings, the proline accumulation increased 3 - fold by the $100 \mathrm{mM} \mathrm{NaCl}$ application, 5 - fold by the $100 \mathrm{mM} \mathrm{NaCl}+\mathrm{Cd}$ application, 8 - fold by the $200 \mathrm{mM}$ $\mathrm{NaCl}$ application, 7 - fold by the $200 \mathrm{mM} \mathrm{NaCl}+\mathrm{Cd}$ application compared to the 
control group and $\mathrm{Cd}$ only application. Hence, the increase in proline accumulation corresponds to the salt application $(\mathrm{p} \leq 0.01)$ (Fig. 3).

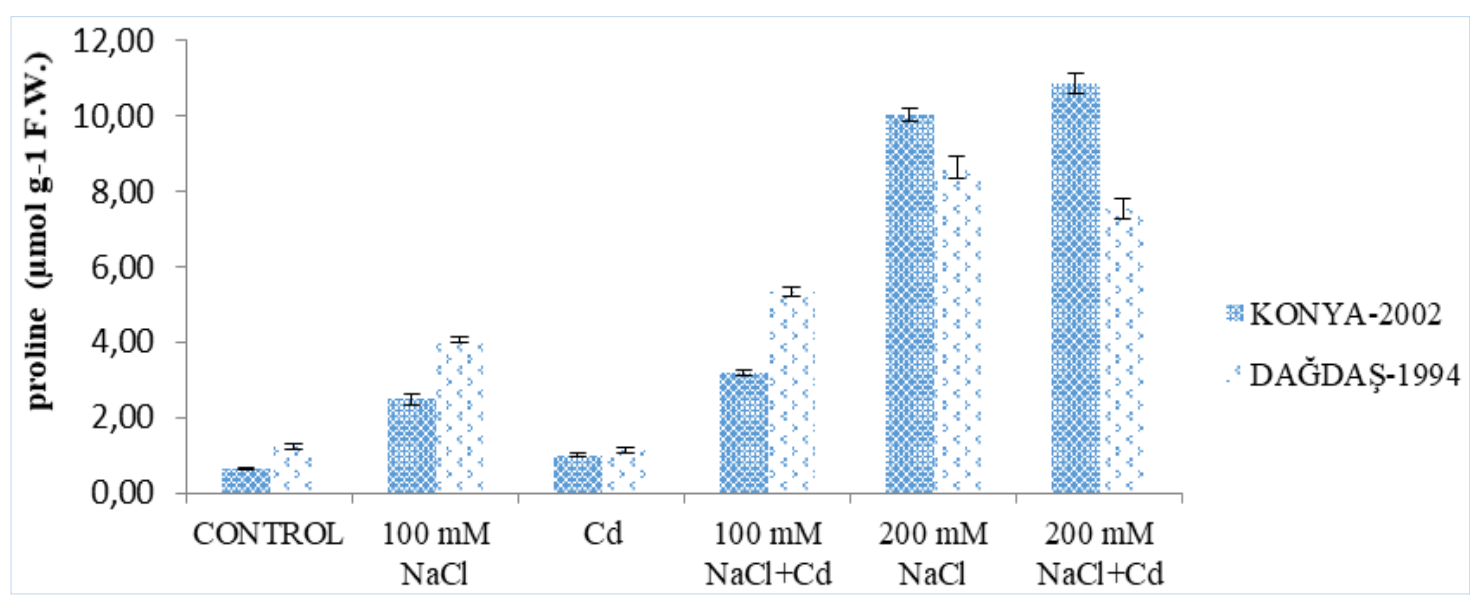

Figure 3. Changes in the content of free proline in wheat (T. aestivum L. cv. Konya-2002 and T. aestivum L. cv. Dağdaş - 94) samples grown under $100 \mathrm{mM} \mathrm{NaCl}, \mathrm{Cd}, 100 \mathrm{mM} \mathrm{NaCl}+\mathrm{Cd}$, $200 \mathrm{mM} \mathrm{NaCl}$ and $200 \mathrm{mM} \mathrm{NaCl}+\mathrm{Cd}$ conditions $(n=3)$

\section{Gene Expressions and Results}

mRNA transcription in T. aestivum L. cv. Konya - 2002 and Dağdaş - 94 varieties exposed to salt and heavy metals were examined by quantitative mRNA analyses via RT - PCR. In qPCR, the number of cycles at which DNAs started to undergo logarithmic amplification $(\mathrm{Ct})$ was less than 35, indicative of efficient DNA amplification. As only one temperature corresponded to each gene in the melt curve analysis, the experimental findings were assessed to be positive. The specific melting temperatures of PCR products were $84.00 \pm 0.50,88.00 \pm 1.00,86.00 \pm 1.00$ and $87 \pm 0.50^{\circ} \mathrm{C}$ for actin, MYB, ERF and SRG, respectively.

\section{TaMYB73 Gene Results}

In this study, the TaMYB73 gene expression in all samples decreased by the application of $\mathrm{Cd}$ and $\mathrm{NaCl}$ compared to the control. Under control conditions, the TaMYB73 gene expression was $\sim 50 \%$ greater in the Konya - 2002 seedlings than in the Dağdaş - 94 seedlings $(\mathrm{p} \leq 0.01)$ (Fig. 4).

\section{TaSRG Gene Results}

The TaSRG gene expression is known to be associated with salt tolerance in plants. The increase in the TaSRG expression in Dağdaş - 94 seedlings exposed to low salt concentrations may be associated with the increase in salt tolerance in the relevant variety. Herein, the cadmium salt $\mathrm{CdCl}_{2}$ was used as the heavy metal. The increase in the TaSRG expression in the Konya - 2002 variety by the application of $\mathrm{Cd}$ was possibly related to the genes related to $\mathrm{Cd}$ stress resistance in the relevant variety. By the comparison of the Konya - 2002 and Dağdaş - 94 varieties of T. aestivum L. wheat seedlings, the Dağdaş - 94 seedlings exhibited an $\sim 3$ - fold increase in the TaSRG gene expressions under $100 \mathrm{mM} \mathrm{NaCl}$ conditions compared to the control. In contrast, gene expression was reduced by $50 \%$ in $200 \mathrm{mM}$ salt administration compared to control and 
by $\sim 90 \%$ compared to $100 \mathrm{mM}$ salt administration ( $\mathrm{p}<0.01$ ). By the application of $\mathrm{Cd}$, the SRG rate the Konya - 2002 variety exhibited a 7 - fold greater increased than that observed for the Dağdaş - 94 variety. Herein, the TaSRG ratio decreased by the applications of $100 \mathrm{mM} \mathrm{NaCl}+10 \mathrm{mM} \mathrm{Cd}, 200 \mathrm{mM} \mathrm{NaCl}$ and $100 \mathrm{mM} \mathrm{NaCl}+10 \mathrm{mM}$ Cd compared to the control in both cultivars $(\mathrm{p} \leq 0.01)$ (Fig. 5).

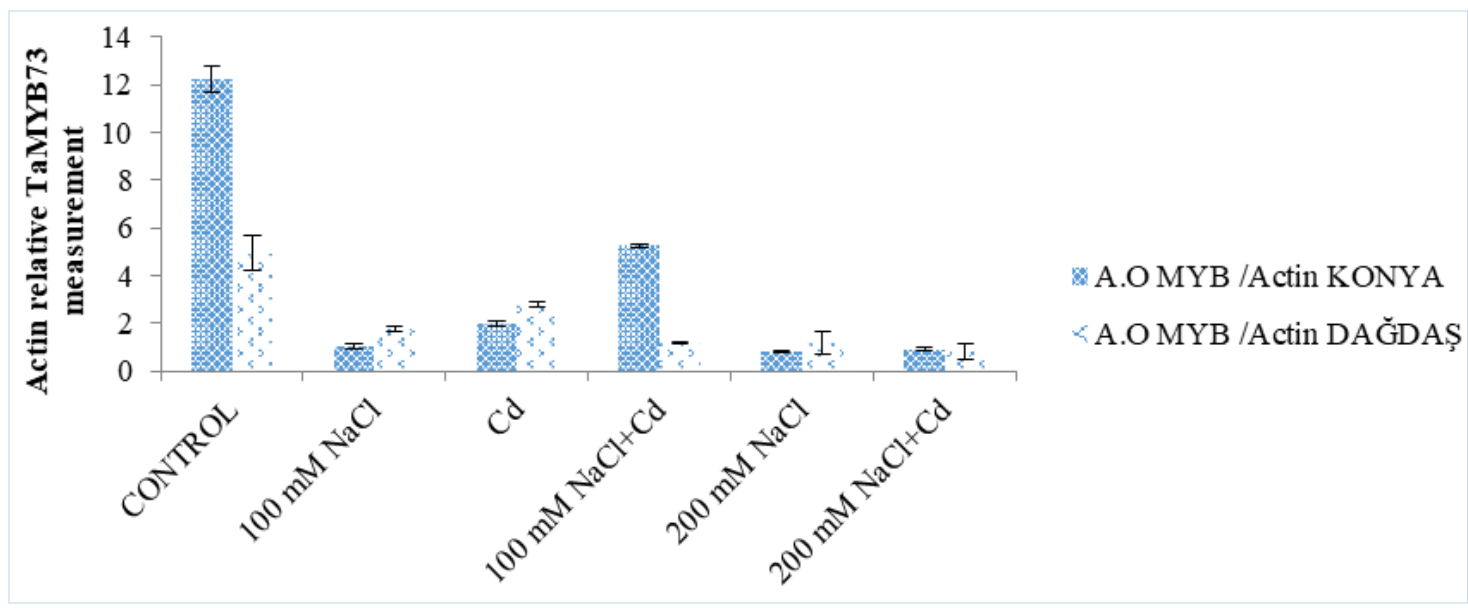

Figure 4. Changes in the TaMYB73 gene expression in wheat (T. aestivum L. cv. Konya - 2002 and T. aestivum L. cv. Dağdaş - 94) samples grown under $100 \mathrm{mM} \mathrm{NaCl}, \mathrm{Cd}, 100 \mathrm{mM} \mathrm{NaCl}+$ $\mathrm{Cd}, 200 \mathrm{mM} \mathrm{NaCl}$ and $200 \mathrm{mM} \mathrm{NaCl}+\mathrm{Cd}$ conditions $(n=3)$

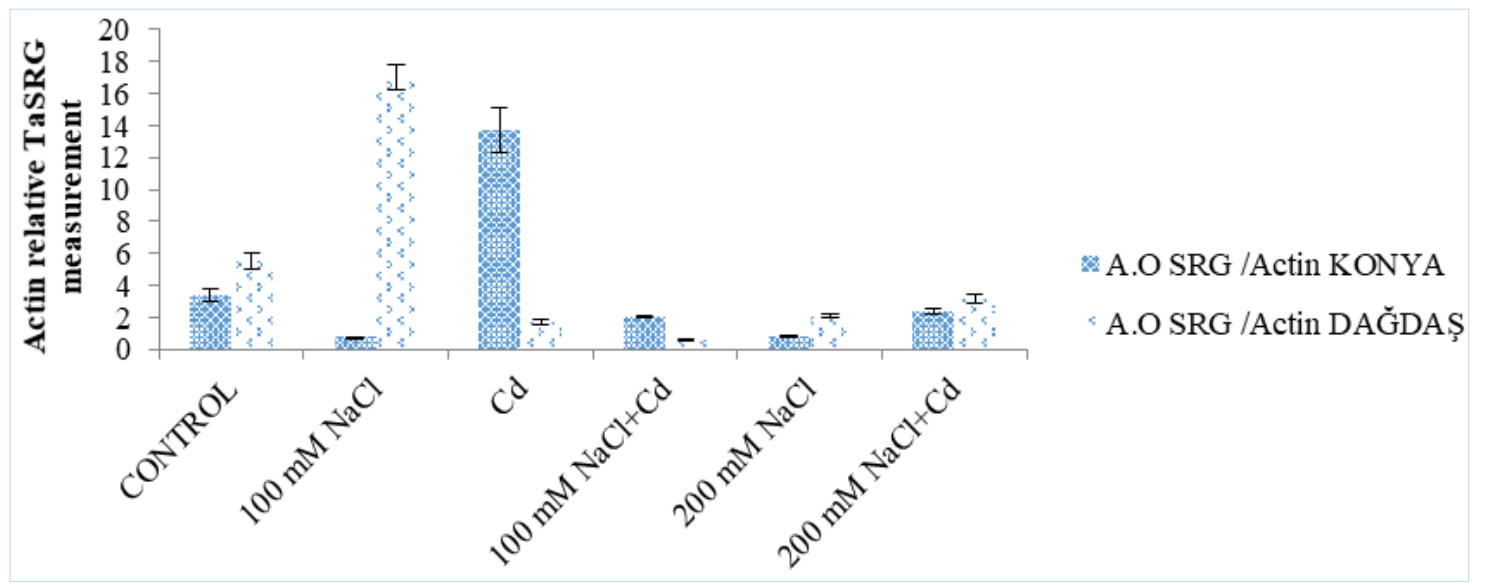

Figure 5. Changes in the TaSRG gene expression in wheat (T. aestivum L. cv. Konya - 2002 and T. aestivum L. cv. Dağdas - 94) samples grown under $100 \mathrm{mM} \mathrm{NaCl}, \mathrm{Cd}, 100 \mathrm{mM} \mathrm{NaCl}+\mathrm{Cd}$, $200 \mathrm{mM} \mathrm{NaCl}$ and $200 \mathrm{mM} \mathrm{NaCl}+\mathrm{Cd}$ conditions $(n=3)$

\section{TaERF - 1 Gene Results}

By the applications of salt, $\mathrm{Cd}$ and salt $+\mathrm{Cd}$ compared to the control $(\mathrm{p} \leq 0.01)$, the Konya - 2002 variety exhibited a 0.25 - fold decrease in the TaERF1/actin ratio. Applications of salt and Cd led to the decrease in the TaERF1/actin ratio; however, by the application of $200 \mathrm{mM} \mathrm{NaCl}+\mathrm{Cd}(\mathrm{p} \leq 0.01)$, the Dağdaş - 94 variety exhibited an $\sim 3$ - fold increase in the TaERF1/actin ratio (Fig. 6). 


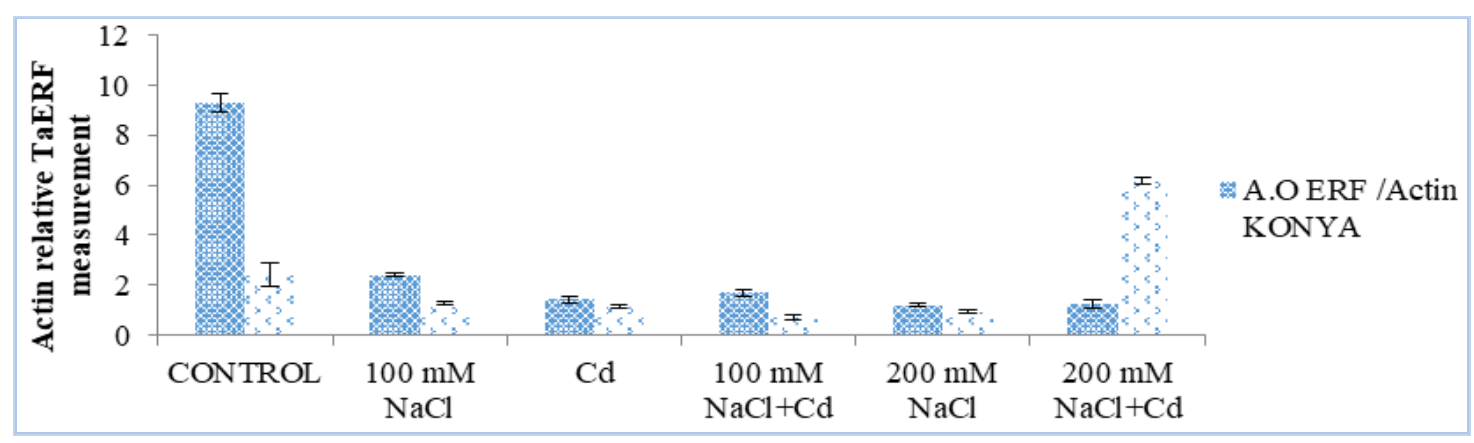

Figure 6. Changes in the TaERF - 1 gene expression in wheat (T. aestivum L. cv. Konya - 2002 and Dağdaş - 94) samples grown under $100 \mathrm{mM} \mathrm{NaCl}, \mathrm{Cd}, 100 \mathrm{mM} \mathrm{NaCl}+\mathrm{Cd}, 200 \mathrm{mM} \mathrm{NaCl}$ and $200 \mathrm{mM} \mathrm{NaCl}+\mathrm{Cd}$ conditions $(n=3)$

\section{Discussion}

It is known, that salinity and heavy metals can cause significant changes in plant expressed genes and metabolism, depending on the plant species, the environment in which they grow. In our study, it was determined that salt and $\mathrm{Cd}$ applications in wheat seedlings of Konya - 2002 and Dağdaş - 94 varieties caused changes in CAT and GR activity levels from antioxidant enzymes.

Antioxidant enzyme levels of plants significantly increase due to stress under stress conditions such as salt and heavy metals, and this increase is related to the elimination of antioxidant compounds. Herein, the significant increase in the GR and CAT activities by the applications of $\mathrm{NaCl}$ and $\mathrm{Cd}$ in both varieties was hypothesized to be related to the removal of free radicals from the environment.

Özçubukçu et al. (2014) have reported the effects of waterlogging (WL) and nitric oxide (NO) in two wheat varieties: Compared to Doğankent seedlings, Ducula - 4 seedlings exhibit a higher CAT activity increase under WL stress, and Ducula - 4 seedlings exhibit an increase in the GR activity under WL - NO conditions, especially at the $48^{\text {th }} \mathrm{h}$ and $72^{\text {nd }} \mathrm{h}$.

Glycine, betaine, proline and soluble carbohydrates exhibit osmoregulatory features; therefore, their concentrations increase under abiotic stress conditions such as salinity and temperature (Ergün and Öncel, 2012; Ergün et al., 2014; Özçubukçu et al., 2014). Proline is a hydrophilic amino acid. Its protective function can be achieved by using glycine, betaine and methionine in some plants. Proline is a key osmotic regulator that ensures the integrity of proteins in plants under salt stress (Ergün and Öncel, 2012).

Plants morphologically, physiologically, and biochemically have been reported to adapt to salinity and water scarcity conditions. These changes occur through gene expressions (Rahaie et al., 2010). MYB transcription factors play an important role in abiotic and biotic stress conditions in plants (Wei et al., 2017). In Wei et al. (2017) TaODORANT1, and R2R3-MYB gene was cloned in wheat (Triticum aestivum L.). This gene localized in the nucleus. Their results revealed that TaODORANT1 overexpression regulated the expression of stress-related genes and some ROS in response to both salt and drought. Wei et al. (2017) reported that TaODORANT1 positively regulated the plant's tolerance to drought and salt stress.

Under salt stress conditions, the TaMYB73 gene has been reported to stimulate $\mathrm{NaCl}$ dehydration and various phytohormones, and the overexpression of the relevant gene 
increases the tolerance to salt stress by playing a role in the ionic stress response in Arabidopsis (He et al., 2012).

Özçubukçu et al. (2014) have reported that the MYB2 gene expression increases by the application of $\mathrm{WL}$ and $\mathrm{WL}+\mathrm{NO}$ in $T$. aestivum $\mathrm{L}$. cv. Doğankent and T. aestivum L. cv. Ducula - 4 wheat seedlings in the first hours of the experiment. MYB is a common transcription factor in plants. The MYB transcription factor has been reported to play a role in plant responses to biotic and abiotic stresses, cell development, signal transfer, etc. (Wang et al., 2016).

The $T$. aestivum salt response gene analysis revealed that the expression of the relevant gene is affected by $\mathrm{NaCl}$, heavy metals and other stress conditions.

Stress - sensitive genes such as SRG genes are involved in the gene expression regulation (Garg and Kumari, 2016). He et al. (2011), have reported that the wheat TaSRG gene acts as a transcription agent in plant varieties and increases tolerance. Also, they have reported that the TaSRG gene function is associated with salt tolerance. Cui et al. (2020) stated that the Arabidopsis zinc finger proteins SRG2 and SRG3 are positive regulators of plant immunity.

Salt stress causes the expression of several genes in plants. These genes encode proteins with different functions, osmotic regulators (Tamura et al., 2003), ion channels (Ward and Schroeder, 1994), carriers (Klein et al., 2004), antioxidant and deoxidant proteins and proteins regulated with special transcription factors (He et al., 2011).

Ethylene is a hormone that regulates physiological conditions in plants, such as fruit development, maturation and ageing. Under abiotic and biotic stress conditions, ERF transcription factors regulate gene expressions.

Factors such as salinity, waterlogging and heavy metal stress adversely affect the growth and yield of plants. Plants exhibit various biochemical and physiological adaptations to abiotic stresses (Cheng et al., 2013). Some plants respond to stress conditions by the increase in various gene expressions. ERF1 transcription factors are among those responsible for the adaptation to biotic and abiotic stress. The overexpression of ERF1 has been reported to increase the tolerance to salt and drought in Arabidopsis (Cheng et al., 2013). Ethylene Sensitive Factor (ERF) plays a role in a variety of plant growth and stress processes (Zhang et al., 2020). TaERF8, a new member of the ERF family, isolated from wheat. Researchers have shown that TaERF8s play a role in the regulation of wheat growth and development.

Ergün et al. (2014) have investigated the effects of heavy metals and temperature to T. aestivum L. cv. Ç - 1252 and Gün - 91 wheat seedlings and reported that the TaMYB73, TaERF1 and TaSRG expressions increase with $\mathrm{Cr}$ and temperature, possibly related to the genes regulating $\mathrm{Cr}$ and temperature responses in wheat.

Wheat seedlings were exposed to salt and heavy metal stress conditions to determine their effects on the development of wheat seedlings, as well as some physiological and biochemical parameters, and examine the expression of some genes under these conditions. Changes in the growth and development of wheat seedlings due to salt and cadmium were examined. Analysis results revealed that the relevant applications lead to the increase and decrease of some parameters.

The antioxidant enzyme content is known to increase in plants under stress, and these enzymes remove free radicals (e.g. $\mathrm{OH}^{-}, \mathrm{H}^{+}$and $\mathrm{H}_{2} \mathrm{O}_{2}$ ) from cells. CAT and GR enzyme activities increased by $\mathrm{NaCl}$ and $\mathrm{Cd}$ applications, and the increase in the Dağdaş - 94 variety was greater than in the Konya - 2002 variety, possibly suggesting that the Dağdaş - 94 variety responds to stress better than the Konya - 2002 variety. The 
significant increase in GR and CAT activities and the increase in the relevant enzymes were hypothesized to be associated with the removal of free radicals from the environment.

The accumulation of free proline in wheat seedlings of the Konya - 2002 and Dağdaş - 94 varieties increased by applications of $100 \mathrm{mM} \mathrm{NaCl}, 100 \mathrm{mM} \mathrm{NaCl}+$ cadmium, cadmium, $200 \mathrm{mM} \mathrm{NaCl}+$ cadmium and $200 \mathrm{mM} \mathrm{NaCl}$. This result was supported by previous studies in that the proline content in plants increases under all stress conditions. Herein, the proline accumulation increased with the salt concentration for the Konya - 2002 and Dağdaş - 94 wheat seedlings; 4 - fold by the low concentration salt application; 5 - fold by the $100 \mathrm{mM} \mathrm{NaCl}$ application and 10 - fold by $200 \mathrm{mM} \mathrm{NaCl}$ and $200 \mathrm{mM} \mathrm{NaCl}+\mathrm{Cd}$ applications compared to the control. The increased accumulation of free proline was possibly related to stress-induced osmoregulation in the plant. Expression of TaMYB73 and TaERF1 genes in both varieties decreased by heavy metal and $\mathrm{NaCl}$ applications compared to the control. By the application of $200 \mathrm{mM} \mathrm{NaCl}+10 \mathrm{mM} \mathrm{Cd}$ compared to the control, the Dağdaş -94 variety exhibited a 3 - fold increase in the TaERF gene expression. The Dağdas - 94 variety of wheat seedlings are resistant to drought. Indeed, the increase in the TaERF1 gene expression by the application of $200 \mathrm{mM} \mathrm{NaCl}+10 \mathrm{mM} \mathrm{Cd}$ was possibly related to the fact that the TaERF1 gene expression increases the salt tolerance of plants. By the low - concentration salt application compared to the control, the Dağdaş - 94 variety exhibited a 3 - fold increase in the TaSRG gene expression; on the other hand, by the application of $\mathrm{Cd}$ compared to the control, the Konya - 2002 variety exhibited a 4 - fold increase in the TaSRG gene expression. On the other hand, the TaSRG ratio decreased by applications of high salt and $\mathrm{NaCl}+\mathrm{Cd}$ compared to the control.

\section{Conclusion}

Abiotic stresses such as salinity and heavy metal stress significantly limit agricultural production. In this study, it is thought that wheat seedlings of Dağdaş - 94 variety are more resistant to salt and cadmium applications than Konya - 2002 variety. Also, the manipulation of salinity tolerance by various genes limits developments in this area. Therefore, more studies are needed to determine enzyme and gene activities, as well as the application of various concentrations to better understand the interactions of salt, cadmium and salt-cadmium interactions.

Acknowledgements. This study is an MSc thesis of Huseyin Dogru and funded by Scientific Research Projects Coordinator (BAP) of Hatay Mustafa Kemal University (17.YL.20).

\section{REFERENCES}

[1] Anonym (2020): Kirmizi buğdaylar (Red wheat). - Available at: http://www.tmo.gov.tr/Upload/Document/digerkirmizibugdaylar.pdf. Access date: 12.15.2020.

[2] Bates, L. S., Waldren, R. P., Teare, I. D. (1973): Rapid determination of free proline for water-stress studies. - Plant and Soil 39: 205-207.

[3] Batir, M. B., Candan, F., Büyük, İ. (2016): Determination of the DNA changes in the artichoke seedlings (Cynara scolymus L.) subjected to lead and copper stresses. - Plant, Soil and Environment 62: 143-149. 
[4] Cakmak, I., Marschner, H. (1992): Magnesium deficiency and high light intensity enhance activities of superoxide dismutase, ascorbate peroxidase, and glutathione reductase in bean leaves. - Plant Physiology 98: 1222-1227.

[5] Cakmak, I. (1994): Activity of ascorbate - dependent $\mathrm{H}_{2} \mathrm{O}_{2}$ - scavenging enzymes and leaf chlorosis are enhanced in magnesium - and potassium - deficient leaves, but not in phosphorus-deficient leaves. - Journal of Experimental Botany 45: 1259-1266.

[6] Cheng, M. C., Liao, P. M., Kuo, W. W., Lin, T. P. (2013): The Arabidopsis Ethylene Response Factor1 regulates abiotic stress-responsive gene expression by binding to different cis-acting elements in response to different stress signals. - Plant Physiology 162: $1566-1582$.

[7] Cui, B., Xu, S., Li, Y., Umbreen, S., Frederickson Matika, D., Yuan, B., Jiang, J., Liu, F., Pan, Q., Loake, G. J. (2020): The arabidopsis zinc finger proteins SRG2 and SRG3 are positive regulators of plant immunity and are differentially regulated by nitric oxide. New Phytologist, https://doi.org/10.1111/nph.16993.

[8] Doğan, R., Çarpıcı, E. B. (2015): Responses of some durum wheat (Triticum turgidum L.) genotypes to salt stress at the germination stage. - Journal of the Faculty of Agriculture Uludağ University 29: 47-55.

[9] Durán, N., Marcato, P. D., De Souza, G. I., Alves, O. L., Esposito, E. (2007): Antibacterial effect of silver nanoparticles produced by fungal process on textile fabrics and their effluent treatment. - Journal of Biomedical Nanotechnology 3: 203-208.

[10] Ergün, N., Öncel, I. (2012): Effects of some heavy metals and heavy metal hormone interactions on wheat (Triticum aestivum L. cv. Gun 91) seedlings. - African Journal of Agricultural Research 7: 1518-1523.

[11] Ergün, N., Özçubukçu, S., Kolukirik, M., Temizkan, Ö. (2014): Effects of temperatureheavy metal interactions, antioxidant enzyme activity and gene expression in wheat (Triticum aestivum L.) seedling. - Acta Biologica Hungarica 65: 439-450.

[12] Garg, G., Kumari, R. (2016): Functional analysis of plants srg-genes/transmembrane protein (RLKs) under stress condition. - Journal of Bioscience and Agriculture Research 9: 827-836.

[13] He, X., Hou, X., Shen, Y., Huang, Z. (2011): TaSRG, a wheat transcription factor, significantly affects salt tolerance in transgenic rice and Arabidopsis. - FEBS Letters 585: 1231-1237.

[14] He, Y., Li, W., Lv, J., Jia, Y., Wang, M., Xia, G. (2012): Ectopic expression of a wheat MYB transcription factor gene, TaMYB73, improves salinity stress tolerance in Arabidopsis thaliana. - Journal of Experimental Botany 63: 1511-1522.

[15] Isayenkov, S. V., Maathuis, F. J. (2019): Plant salinity stress: many unanswered questions remain. - Frontiers in Plant Science 10: 1-11.

[16] Klein, M., Geisler, M., Suh, S. J., Kolukısaoğlu, H. U., Azevedo, L., Plaza, S., Curtis, M. D., Richter, A., Weder, B., Schulz, B., Martinoia, E. (2004): Disruption of AtMRP4, a guard cell plasma membrane ABCC-type $\mathrm{ABC}$ transporter, leads to deregulation of stomatal opening and increased drought susceptibility. - The Plant Journal 39: 219-236.

[17] Livak, K. J., Schmittgen, T. D. (2001): Analysis of relative gene expression data using real-time quantitative PCR and the2- $\Delta \Delta \mathrm{CT}$ method. - Methods 25: 402-408.

[18] Öncel, I., Keleş, Y., Üstün, A. S. (2000): Interactive effects of temperature and heavy metal stress on the growth and some biochemical compounds in wheat seedlings. Environmental pollution 107: 315-320.

[19] Özçubukçu, S., Ergün, N., Ilhan, E. (2014): Waterlogging and nitric oxide induce gene expression and increase antioxidant enzyme activity in wheat (Triticum aestivum L.). Acta Biologica Hungarica 65: 47-60.

[20] Öztürk, A., Aydin, M. (2017): Physiological characterization of Turkish bread wheat genotypes for resistance to late drought stress. - Turkish Journal of Agriculture and Forestry 41: 414-440. 
[21] Rahaie, M., Xue, G. P., Naghavi, M. R., Alizadeh, H., Schenk, P. M. (2010): A MYB gene from wheat (Triticum aestivum L.) is up-regulated during salt and drought stresses and differentially regulated between salt-tolerant and sensitive genotypes. - Plant Cell Reports 29: 835-844.

[22] Tamura, T., Hara, K., Yamaguchi, Y., Koizumi, N., Sano, H. (2003): Osmotic stress tolerance of transgenic tobacco expressing a gene encoding a membrane - located receptor-like protein from tobacco plants. - Plant Physiology 131: 454-462.

[23] Tirry, N., Joutey, N. T., Sayel, H., Kouchou, A., Bahafid, W., Asri, M., El Ghachtouli, N. (2018): Screening of plant growth-promoting traits in heavy metals resistant bacteria: prospects in phytoremediation. - Journal of Genetic Engineering and Biotechnology 16: 613-619.

[24] Wang, H., Wang, H., Shao, H., Tang, X. (2016): Recent advances in utilizing transcription factors to improve plant abiotic stress tolerance by transgenic technology. Frontiers in Plant Science 7: 67.

[25] Ward, J. M., Schroeder, J. I. (1994): Calcium-activated $\mathrm{K}^{+}$channels and calcium-induced calcium release by slow vacuolar ion channels in guard cell vacuoles implicated in the control of stomatal closure. - The Plant Cell 6: 669-683.

[26] Wei, Q., Luo, Q., Wang, R., Zhang, F., He, Y., Zhang, Y., Qui, D., Li, K., Chan, J., Yang, G., He, G. (2017): A wheat R2R3-type MYB transcription factor TaODORANT1 positively regulates drought and salt stress responses in transgenic tobacco plants. Frontiers in Plant Science 8: 1374.

[27] Zhang, L., Liu, P., Wu, J., Qiao, L., Zhao, G., Jia, J., Gao, L., Wang, J. (2020): Identification of a novel ERF gene, TaERF8, associated with plant height and yield in wheat. - BMC Plant Biology 20: 1-12. 